\title{
Temperature Dependence of the Magnetic and Electric Properties of $\mathrm{Ca}_{2} \mathrm{Fe}_{2} \mathrm{O}_{5}$
}

\author{
Cléber Candido da Silva ${ }^{1,2^{*}}$, Antonio S. B. Sombra ${ }^{1}$ \\ ${ }^{1}$ Telecommunications and Materials Science and Engineering Laboratory (LOCEM), Department of Physics, Federal University of \\ Ceará, Campus do Pici, Fortaleza, Ceará, Brazil; ${ }^{2}$ Universidade Federal do Maranhão (UFMA), Centro de Ciências Sociais, Saúde e \\ Tecnologia (CCSST), Departamento de Engenharia de Alimentos, Campus II, Imperatriz, MA, Brazil. \\ Email: ${ }^{*}$ cleber.silva@pq.cnpq.br, cleber@ufma.br
}

Received April $6^{\text {th }}, 2011$; revised April 25 ${ }^{\text {th }}$, accepted July $5^{\text {th }}, 2011$.

\begin{abstract}
$\mathrm{Ca}_{2} \mathrm{Fe}_{2} \mathrm{O}_{5}$ powder sample, were prepared to investigate the origin of the weak ferromagnetic component reported in literature for calcium ferrite single crystals. In this work, the calcination method was used to produce nanocrystalline powders of $\mathrm{Ca}_{2} \mathrm{Fe}_{2} \mathrm{O}_{5}$. XRD measurement has shown the presence of $\mathrm{Fe}_{3} \mathrm{O}_{4}$ magnetite and $\mathrm{CaO}$ as impurity phases. The ferrimagnetic phase deeply influences the magnetic behavior with features very similar to those reported in literature for $\mathrm{Ca}_{2} \mathrm{Fe}_{2} \mathrm{O}_{5}$, both powders and single crystals. Our results support the hypothesis that the weak ferromagnetic component observed in $\mathrm{Ca}_{2} \mathrm{Fe}_{2} \mathrm{O}_{5}$ can be also due to the presence of magnetite impurity traces in the samples. The powders were submitted to calcination processes at $500^{\circ} \mathrm{C}$ for 2 hours and $950^{\circ} \mathrm{C}$ for 16 hours. The sintered sample was submitted at $1050^{\circ} \mathrm{C}$ for 6 hours and characterized by X-Ray Powder diffraction (XRD), dielectric measurements, Magnetization and Scanning Electron Microscopy (SEM) analysis.
\end{abstract}

Keywords: $\mathrm{Ca}_{2} \mathrm{Fe}_{2} \mathrm{O}_{5}$, Dielectric Measurements, Magnetization

\section{Introduction}

$\mathrm{CF}\left(\mathrm{Ca}_{2} \mathrm{Fe}_{2} \mathrm{O}_{5}\right)$ is a member of the family of com- pounds with general formula $\mathrm{A}_{2} \mathrm{~B}_{2} \mathrm{O}_{5}(\mathrm{~A}=\mathrm{Ca}, \mathrm{Sr} ; \mathrm{B}=\mathrm{Fe}, \mathrm{Al})$, and it finds application in the field of catalysis, when obtained from mechano-chemical synthesis [1]. Its structure is the one known for the Srebrodolskite mineral $[2,3]$ and it is related to the perovskite $\left(\mathrm{ABO}_{3}\right)$ structure by the introduction of an ordered array of oxygen vacancies and the creation of an alternate layer structure of octahedrally and tetrahedrally coordinated transition metal cations. The iron end-member CF [4,5] (mineral name srebrodolskite) adopts space group Pnma at ambient conditions $(\mathrm{a}=5.4, \mathrm{~b}=14.8, \mathrm{c}=5.6 \AA)$. Their magnetic structures and properties have been investigated by many authors [6-12]. Physical properties of CF, such as electronic and oxygen-ionic transport [13] and catalytic [14] and photo catalytic [15] behavior, have been studied. Usage as catalyst for the combustion of volatile organic compounds $[16,17]$ and for direct decomposition of $\mathrm{NO}_{\mathrm{x}}$ in exhaust streams $[18,19]$ has been examined. Numerous entries in patent data bases also highlight a strong interesting brownmillerites for catalytic applications. Brownmillerite type structures exhibit two different layers, al- ternately stacked: 1) perovskite-like sheets of octahedrally co-ordinated $\mathrm{B}$ cations and 2) layers of $\mathrm{BO}_{4}$ tetrahedra, which are corner-linked to form parallel zweier single chains. Mixed occupations are observed frequently. Two phase transitions are known for the iron end-member CF: the loss of the antiferromagnetic order at the Neel temperature at $720 \mathrm{~K}[7-9,20]$ and a structural phase transition [12,20-22] at $950 \mathrm{~K}$. The high-temperature phases of the end-members $\mathrm{Ca}_{2} \mathrm{Fe}_{2} \mathrm{O}_{5}$ and $\mathrm{Ca}_{2} \mathrm{Al}_{2} \mathrm{O}_{5}$ turned out to be isotypic modulated structures [6,23], with an aperiodic sequence of tetrahedral chains. These structures are described using the $(3+1)$-dimensional super space approach [24]. Their super space group is $\operatorname{Imma}(00 \gamma) \mathrm{s} 00$. The main purpose of the work is to prepare CF ceramic and study the effect of the analyses of the magnetic momentum versus magnetic field $(\mathrm{H})$ and dielectric comportment. X-Ray diffraction and Scanning Electron Microscopy (SEM) analysis were also done to characterize such ceramic.

\section{Experimental}

CF crystalline powders were prepared by stoichiometric quantities of $\mathrm{CaCO}_{3}$ (Aldrich 99\%) and $\mathrm{Fe}_{2} \mathrm{O}_{3}$ (Al- 
drich $98 \%$ ) were the mixtures were submitted to heattreatment at $500^{\circ} \mathrm{C}$ during $2 \mathrm{~h}$ and $950^{\circ} \mathrm{C}$ during $16 \mathrm{~h}$ both with a heating rate of $3^{\circ} \mathrm{C} / \mathrm{min}$. Equation (1) represents the expected chemical reaction:

$$
2 \mathrm{CaCO}_{3}+\mathrm{Fe}_{2} \mathrm{O}_{3} \rightarrow \mathrm{Ca}_{2} \mathrm{Fe}_{2} \mathrm{O}_{3}+2 \mathrm{CO}_{2}
$$

\section{X-Ray Diffraction}

The X-ray diffraction (XRD) patterns data were obtained at room temperature using powder samples in an X'Pert MPD Philips difractometer (with $\mathrm{K}_{\alpha}$ radiation, $\lambda=$ $1.54056 \AA$ ) at $40 \mathrm{KV}$ and $30 \mathrm{~mA}$. Intensity data were collected by the step counting method (step $0.02^{\circ}$ and a time per step of $1 \mathrm{~s}$ ) between $20^{\circ}$ and $60^{\circ}(2 \theta)$. The analysis of the crystallite size $\left(L_{c}\right)$ of the $\mathrm{Ca}_{2} \mathrm{Fe}_{2} \mathrm{O}_{5}$ phase has been done using the Scherrer's equation $[\mathrm{A}]$ :

$$
L_{c}=\frac{k \lambda}{\beta \cos \theta}
$$

where $k$ is the shape coefficient ( $k=1$ was chosen, considering that the shape of this point is spherical), $\lambda$ the wave length, $\beta$ the full width at half maximum (FWHM) of the peak of each phase and $\theta$ the diffract- tion angle. For this purpose, we chose the avarege of peak within the pattern and according to Pnma space group of $\mathrm{Ca}_{2} \mathrm{Fe}_{2} \mathrm{O}_{5}$. This peak corresponded to $h k l=141$, both along the $c$ crystallographic axis.

\section{VSM}

The magnetization $(\mathrm{M} / \mathrm{H})$ was measured using an Oxford Instruments VSM (Vibrating Sample Magne- tometer) between 1.6 and $300 \mathrm{~K}$, on a field-cooled sample, under an applied field of 100 Oe.

\section{SEM}

The morphological analysis of the sample structure was performed using the scanning electron microscopy (SEM), Philips XL-30, operating with bunches of primary electrons ranging from 12 to $20 \mathrm{keV}$.

\section{Results and Discussions}

Figure 1 present $\mathrm{XRD}$ pattern of the $\mathrm{CF}$ calcinated at $950^{\circ} \mathrm{C}$. Brownmillerite or srebrodolskite $\left(\mathrm{Ca}_{2} \mathrm{Fe}_{2} \mathrm{O}_{5}\right)$ [25] was identified. This structure $\left(\mathrm{Ca}_{2} \mathrm{Fe}_{2} \mathrm{O}_{5}\right)$ can be seen like a perovskite deficient in oxygen, where as brownmillerite $\left(\mathrm{A}_{2} \mathrm{~B}_{2} \mathrm{O}_{5}\right)$ is a kind of oxygen-deficient perovskite structure that is composed of perovskite-like three-dimensional framework of corner-sharing $\mathrm{BO}_{6}$ octahedra alternating with slabs containing rows of corner-sharing $\mathrm{BO}_{4}$ tetrahedra which are formed by the deficiency of oxygen during the formation of the structure [26]. The little impurity peaks $(\bullet)$ and $(\diamond)$ indicate the formation of $\mathrm{Fe}_{3} \mathrm{O}_{4}$ [25] and $\mathrm{CaO}$ [25] phases respectively were detected in the XRD of the sample (Figure 1). In addition, investigations of magnetic resonance are of special interest, since $\mathrm{Ca}_{2} \mathrm{Fe}_{2} \mathrm{O}_{5}$ is a many-sublattice system with

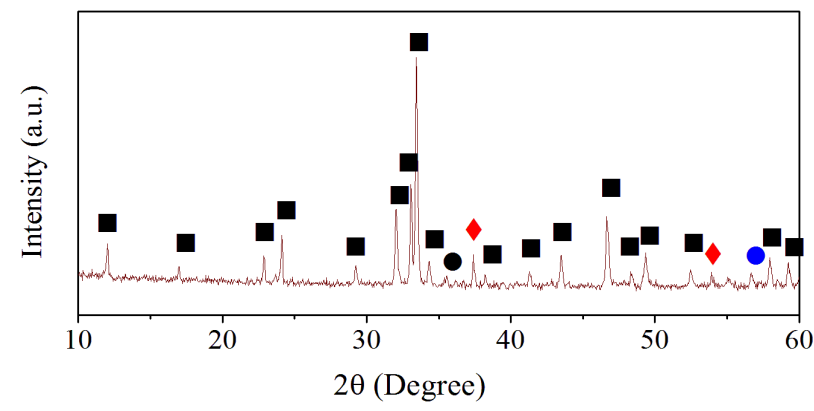

Figure 1. XRD pattern of the sample. $\mathrm{Ca}_{2} \mathrm{Fe}_{2} \mathrm{O}_{5}(\square), \mathrm{Fe}_{3} \mathrm{O}_{4}$ $(\mathrm{O})$ and $\mathrm{CaO}(\diamond)[25]$.

a nontrivial magnetic layer structure [27]. The Figure 2 exhibits the variation of $M^{\prime \prime}$ with frequency for $\mathrm{CF}$ at different temperatures. A well-defined relaxation mechanism is observed in the temperature range of $303-353 \mathrm{~K}$. The relaxation peaks shift towards higher fre- quencies with increasing on temperature. For sample, a single peak is observed. The presence of such relaxation peaks in the $M^{\prime \prime}$ plots indicates that the samples are ionic conductors [28]. The nature of the variation of $\sigma_{d c}(10$ $\mathrm{KHz}$ ) vs. $1000 / \mathrm{T}$ and $f_{\max }$ (peak maximum, Figure 2) vs. 1000/T with temperature follows the Arrhenius relation 3 and 4 respectively:

$$
\begin{aligned}
& f=f_{o} \exp \left[-\frac{E_{a}}{k T}\right] \\
& \sigma=\sigma_{o} \exp \left[-\frac{E_{a}}{k T}\right]
\end{aligned}
$$

where $f_{0}$ and $\sigma_{0}$ is a pre-exponential factor, $E_{a}$ is the activation energy; $k$ is the Boltzmann constant; and $T$ the absolute temperature [29].

The activation energy calculated from the modulus spectrum $(0.20 \mathrm{eV})$ is also comparable to the value

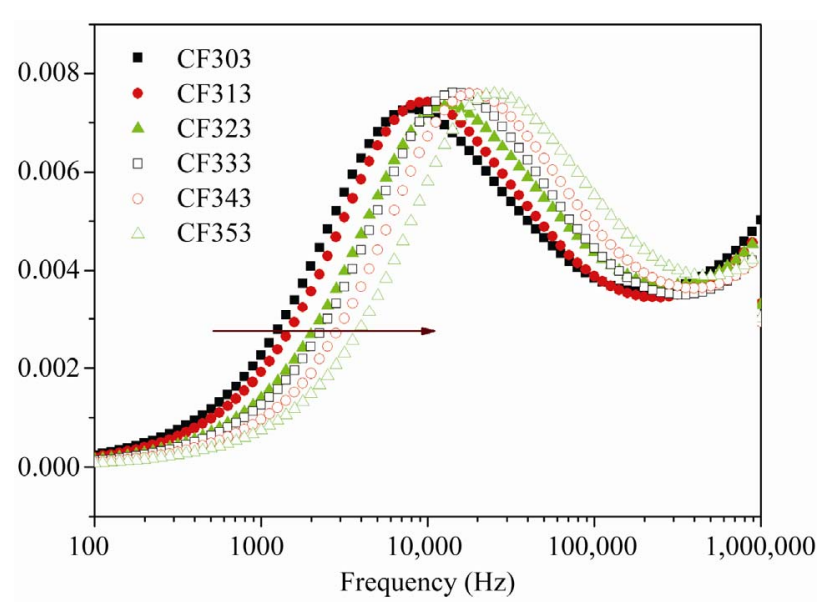

Figure 2. The temperature dependence of the of the Imaginary Modulus of the CF sample, from 303 to $353 \mathrm{~K}$. 
obtained from the conductivity $(0.18 \mathrm{eV})$ (Figure 3). The comparable values of the activation energy of both conductivity and modulus spectra indicate that the relaxation and conductivity process may be attributed to the same type of charge carries [30]. Figure 4 shows the magnetization as a function of temperature. There is a decrease of the magnetization with the increase in temperature characteristic of the brownmillerite. The $\mathrm{Ca}_{2} \mathrm{Fe}_{2} \mathrm{O}_{5}$ structure is a weak antiferromagnet directed along the c-axis [27]. This observation shows that the magnetocrystalline anisotropy in the a-c plane is small. The influence of $\mathrm{Fe}_{3} \mathrm{O}_{4}$ on the magnetic behavior not is observed. The micrographics (Figure 5(a) and (b)) showed particles of the sample $\mathrm{CF}$, where the micro-structures demonstrate average grain size of $0.61 \mu \mathrm{m}$, while the crystallites for that sample obtained by the diffraction of x-ray range from $70.92 \pm 3.38 \mathrm{~nm}$ indicating the presence of large agglomerates of particles due to the sintering process. The reason for this morphology depends to the sintering

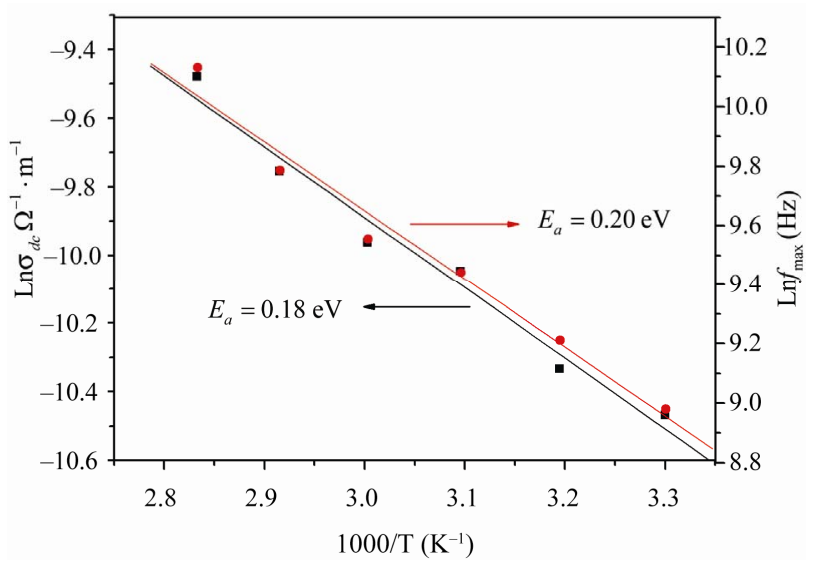

Figure 3. odc (10 KHz) vs. 1000/T (ם) and fmax (peak maximum in Imaginary Modulos of CF) vs. 1000/T (O).

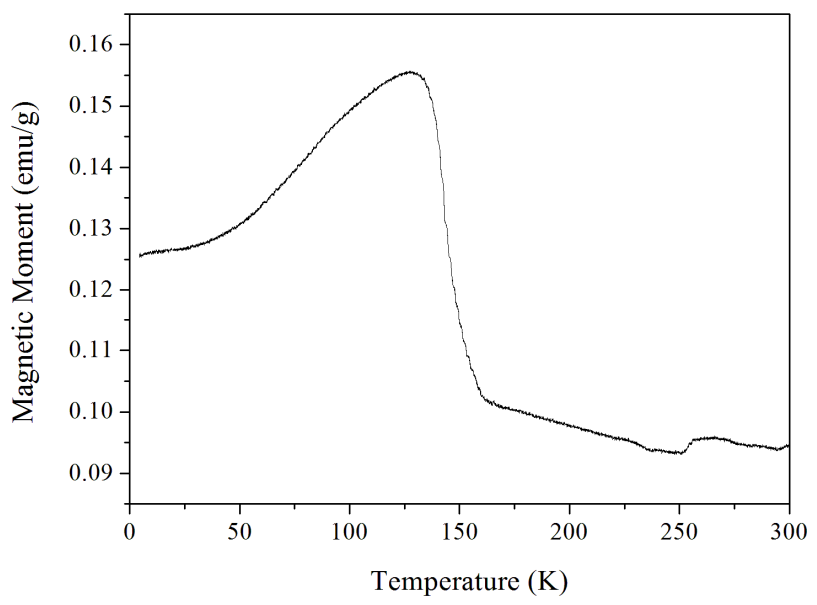

Figure 4. Temperature Dependence of the Magnetization for the CF sample, from 1.6 to $300 \mathrm{~K}$.

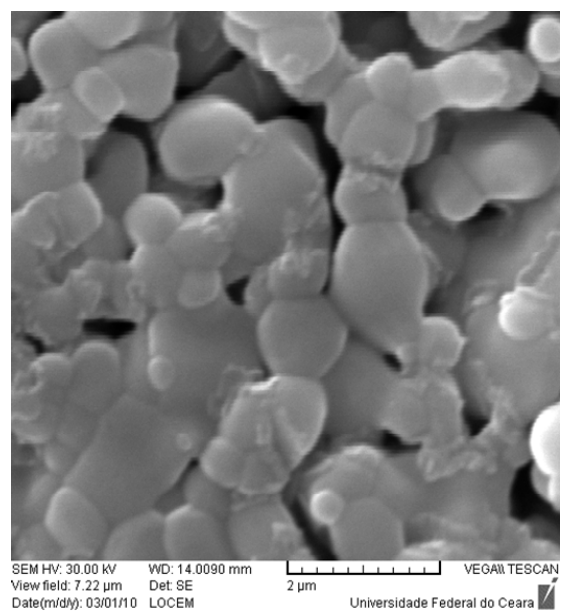

(a)

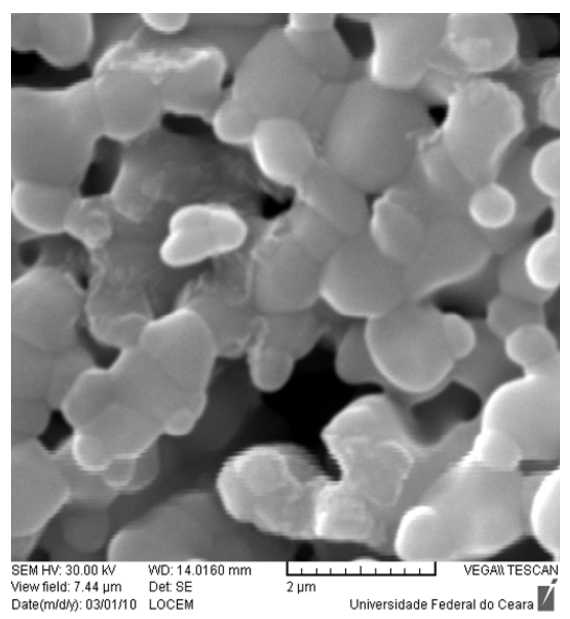

(b)

Figure 5. SEM of the CF sample with 20.000X ((a) and (b)).

effect, where, probably, the formation of $\mathrm{Fe}_{3} \mathrm{O}_{4}$ phase changes the grain size in sample.

\section{Conclusions}

$\mathrm{Ca}_{2} \mathrm{Fe}_{2} \mathrm{O}_{5}$ (brownmillerite) phase was obtained with the presence of impurity phases $\left(\mathrm{Fe}_{3} \mathrm{O}_{4}\right.$ and $\left.\mathrm{CaO}\right)$ probably due heat-treated at $950^{\circ} \mathrm{C}$. The comparable values of the activation energy of both conductivity and modulus spectra indicate that the relaxation and conductivity process may be attributed to the same type of charge carries. The VSM analysis show that the $\mathrm{Ca}_{2} \mathrm{Fe}_{2} \mathrm{O}_{5}$ structure is a weak antiferromagnet directed along the c-axis. Between 75 and $150 \mathrm{~K}$ we have a decrease of the magnetization with the temperature characteristic of the brownmillerite [27]. This observation shows that the magnetocrystalline anisotropy in the a-c plane is small. The crystallites for that sample obtained by the diffraction of $\mathrm{x}$-ray $(70.92 \pm 3.38 \mathrm{~nm})$ indicating the presence of large agglomerates of particles due to the sintering process 
where the formation of $\mathrm{Fe}_{3} \mathrm{O}_{4}$ phase changes the grain size in sample.

\section{Acknoledgements}

The authors thank this work to the Telecommunications and Materials Science and Engineering Laboratory (LOCEM) Physics Department, Federal, University of Ceará-Brazil.

\section{REFERENCES}

[1] L. A. Isupova, S. W. Tsybulya, G. N. Kryukova, A. A. Budneva, E. A. Paukshtis, G. S. Litvak, V. P. Ivanov, V. N. Kolomiichuk, Yu. T. Pavlyukhin and V. A. Sadykov, "Mechanochemical Synthesis and Catalytic Properties of the Calcium Ferrite $\mathrm{Ca}_{2} \mathrm{Fe}_{2} \mathrm{O}_{5}$," Kinetics and Catalysis, Vol. 43, No. 1, 2002, pp. 122-128. doi:10.1023/A:1014217716883

[2] A. A. Colville, "Structural Crystallography and Crystal Chemistry," Acta Crystallographica, Vol. B26, 1970, pp. 1469-1473.

[3] J. Berggren, "Refinement of the Crystal Structure of Dicalcium Ferrite, $\mathrm{Ca}_{2} \mathrm{Fe}_{2} \mathrm{O}_{5}$," Acta Chemica Scandinavica, Vol. 25, 1971, pp. 3616-3624.

doi:10.3891/acta.chem.scand.25-3616

[4] E. F. Bertaut, P. Blum and A. Sagnières, "Structure du ferrite bicalcique et de la brownmillerite," Acta Crystallographica, Vol. 12, No. 2, 1959, pp. 149-159. doi:10.1107/S0365110X59000433

[5] V. A. Sadykov, L. A. Isupova, S. F. Tikhov and O. N. Kimkhai, "Synthesis and Properties of Advanced Ceramic Materials," Materials Research Society Symposium Series, MRS Fall Meeting, Vol. 386, 1995, p. 293.

[6] B. Lazić, H. Krüger, V. Kahlenberg, J. Konzett and R. Kaindl, "Incommensurate Structure of $\mathrm{Ca}_{2} \mathrm{Al}_{2} \mathrm{O}_{5}$ at High Temperatures-Structure Investigation and Raman Spectroscopy," Acta Crystallographica, Vol. B64, No. 4, 2008, pp. 417-425.

[7] L. M. Corliss, J. M. Hastings, W. Kunnmann and E. Banks, "Magnetic Structures and Exchange Interactions in the Systems $\mathrm{CaCr}_{x} \mathrm{Fe}_{2-x} \mathrm{O}_{4}$ and $\mathrm{Ca}_{2} \mathrm{Cr}_{x} \mathrm{Fe}_{2-x} \mathrm{O}_{5}$," Acta Crystallographica, Vol. 21, 1966, p. A95.

[8] R. W. Grant, S. Geller, H. Wiedersich, U. Gonser and L. D. Fullmer, "Spin Orientation and Magnetic Properties of $\mathrm{Ca}_{2} \mathrm{FeAlO}_{5}$," Journal of Applied Physics, Vol. 39, No. 2, 1968, pp. 1122-1123. doi:10.1063/1.1656192

[9] T. Takeda, Y. Yamaguchi, S. Tomiyoshi, M. Fukase, M. Sugimoto, H. Watanabe, "Magnetic Structure of $\mathrm{Ca}_{2} \mathrm{Fe}_{2} \mathrm{O}_{5}$," Journal of the Physical Society of Japan, Vol. 24, No. 3, 1968, pp. 446-452. doi:10.1143/JPSJ.24.446

[10] S. Geller, R. W. Grant and L. D. Fullmer, "Magnetic Structures in the $\mathrm{Ca}_{2} \mathrm{Fe}_{2-x} \mathrm{Al}_{x} \mathrm{O}_{5}$ System," Journal of Physics and Chemistry of Solids, Vol. 31, No. 4, 1970, pp. 793-803. doi:10.1016/0022-3697(70)90213-1

[11] S. Geller, R. W. Grant and U. Gonser, "Crystal Chemistry and Magnetic Structures of Substituted $\mathrm{Ca}_{2}[\mathrm{Fe}](\mathrm{Fe}) \mathrm{O}_{5}$," Progress in Solid State Chemistry, Vol. 5, 1971, pp. 1-26.
doi:10.1016/0079-6786(71)90015-X

[12] P. Berastegui, S. G. Eriksson and S. Hull, "A Neutron Diffraction Study of the Temperature Dependence of $\mathrm{Ca}_{2} \mathrm{Fe}_{2} \mathrm{O}_{5}$," Materials Research Bulletin, Vol. 34, No. 2, 1999, pp. 303-314. doi:10.1016/S0025-5408(99)00007-0

[13] A. L. Shaula, Y. V. Pivak, J. C. Waerenborgh, P. Gaczyñski, A. A. Yaremchenko and V. V. Kharton, "Ionic Conductivity of Brownmillerite-Type Calcium Ferrite under Oxidizing Conditions," Solid State Ionics, Vol. 177, No. 33-34, 2006, pp. 2923-2930. doi:10.1016/j.ssi.2006.08.030

[14] C. N. R. Rao and J. Gopalakrishnan, "New Directions in Solid State Chemistry: Structure, Synthesis, Properties, Reactivity, and Materials Design," Cambridge University Press, Cambridge, 1986.

[15] Y. Yang, Z. Cao, Y. Jiang, L. Liu and Y. Sun, "Photoinduced Structural Transformation of $\mathrm{SrFeO}_{3}$ and $\mathrm{Ca}_{2} \mathrm{Fe}_{2} \mathrm{O}_{5}$ during Photodegradation of Methyl Orange," Materials Science and Engineering: B, Vol. 132, No. 3, 2006, pp. 311-314. doi:10.1016/j.mseb.2006.03.031

[16] D. Hirabayashi, T. Yoshikawa, K. Mochizuki, K. Suzuki and Y. Sakai, "Formation of Brownmillerite Type Calcium Ferrite $\left(\mathrm{Ca}_{2} \mathrm{Fe}_{2} \mathrm{O}_{5}\right)$ and Catalytic Properties in Propylene Combustion," Catalysis Letters, Vol. 110, No. 3-4, 2006, pp. 269-274. doi:10.1007/s10562-006-0120-0

[17] D. Hirabayashi, Y. Kawamoto and K. Suzuki, "Catalytic Decomposition of Vocs and Chlorine Fixation on Calcium Ferrites with Brownmillerite Type Structure," Journal of the Society of Inorganic Materials, Japan, Vol. 14, No. 327, 2007, pp. 83-91.

[18] S. Shin, Y. Hatakeyama, K. Ogawa and K. Shimomura, "Catalytic Decomposition of Nitric Oxide over Brownmillerite-Like Compounds, Calcium Ferrate(III) $\left(\mathrm{Ca}_{2} \mathrm{Fe}_{2} \mathrm{O}_{5}\right)$ and Strontium Ferrate(III) $\left(\mathrm{Sr}_{2} \mathrm{Fe}_{2} \mathrm{O}_{5}\right)$," Materials Research Bulletin, Vol. 14, No. 1, 1979, pp. 133-136. doi:10.1016/0025-5408(79)90241-1

[19] J. H. White, A. F. Sammells and J. D. Wander, "Catalysts for Direct Decomposition of NOx in Exhausts," Proceedings of the 93rd Air and Waste Management Association's Annual Conference and Exhibition, Salt Lake City, UT, United States, 2000.

[20] E. Woermann, W. Eysel, T. Hahn, "Polymorphism and Solid Solution of the Ferrite Phase," Proceedings of the Fifth International Symposium on the Chemistry of Cement, Tokyo, Supplementary Paper I-54, 1968, pp. 5460.

[21] G. J. Redhammer, G. Tippelt, G. Roth and G. Amthauer, "Structural Variations in the Brownmillerite Series $\mathrm{Ca}_{2}\left(\mathrm{Fe}_{2-x} \mathrm{Al}_{x}\right) \mathrm{O}_{5}$ : Single-Crystal X-Ray Diffraction at $25 \pm^{\circ} \mathrm{C}$ and High-Temperature X-Ray Powder Diffraction $\left(25 \pm^{\circ} \mathrm{C} \cdot \mathrm{T} \cdot 1000 \pm{ }^{\circ} \mathrm{C}\right), "$ American Mineralogist, Vol. 89, 2004, pp. 405-420.

[22] K. Fukuda and H. Ando, "Determination of the $P c m n=I b m 2$ Phase Boundary at High Temperatures in the System $\mathrm{Ca}_{2} \mathrm{Fe}_{2} \mathrm{O}_{5}-\mathrm{Ca}_{2} \mathrm{Al}_{2} \mathrm{O}_{5}$," Journal of the American Ceramic Society, Vol. 85, No. 5, 2002, pp. 1300-1303. doi:10.1111/j.1151-2916.2002.tb00263.x 
[23] H. Krüger and V. Kahlenberg, "Incommensurately Modulated Ordering of Tetrahedral Chains in $\mathrm{Ca}_{2} \mathrm{Fe}_{2} \mathrm{O}_{5}$ at Elevated Temperatures," Acta Crystallographica Section $B$, Vol. 61, No. 6, 2005, pp. 656-662.

[24] T. Janssen, A. Janner, A. Looijenga-Vos and P. M. de Wolff, "Mathematical, Physical and Chemical Tables, Incommensurate and Commensurate Modulated Structures," Kluwer Academic Publishers, Dordrecht, 2004.

[25] JCPDS-Pattern 38-0408 $\left(\mathrm{Ca}_{2} \mathrm{Fe}_{2} \mathrm{O}_{5}\right), 03-0863\left(\mathrm{Fe}_{3} \mathrm{O}_{4}\right)$ and $82-1690(\mathrm{CaO})$.

[26] I. G. Minyaylova, I. A. Presnyakov, K. V. Pokholok, A. V. Sobolev, A. V. Baranov, G. Demazeau, G. A. Govor and A. K. Vetcher, "Hyperfine Interactions and Dynamic Characteristics of ${ }^{119} \mathrm{Sn}$ Dopant Atoms in $\mathrm{Ca}_{2} \mathrm{Fe}_{2} \mathrm{O}_{5}$," Journal of Solid State Chemistry, Vol. 151, No. 2, 2000, pp. 313-316. doi:10.1006/jssc. 2000.8660

[27] C. Brotzeller, R. Geick and P. Marchukov, "Magnetic
Excitations in Dicalcium Ferrite," Solid State Communications, Vol. 82, No. 11, 1992, pp. 923-925. doi:10.1016/0038-1098(92)90721-K

[28] B. Yang, J. Zhou, Z. Gui, Z. Yue and L. Li, "Preparation and Magnetic Characterization of Y-Type Hexaferrites Containing Zinc, Cobalt and Copper," Materials Science and Engineering B, Vol. 99, No. 1-3, 2003, pp. 266-269. doi:10.1016/S0921-5107(02)00545-7

[29] K. P. Padmasree, D. K. Kanchan, A. R. Kulkami, "Impedance and Modulus Studies of the Solid Electrolyte System $20 \mathrm{CdI}_{2}-80\left[x \mathrm{Ag}_{2} \mathrm{O}-y\left(0.7 \mathrm{~V}_{2} \mathrm{O}_{5}-0.3 \mathrm{~B}_{2} \mathrm{O}_{3}\right)\right]$, Where 1 $\leq x / y \leq 3$," Solid State Ionics, Vol. 177, No. 5-6, 2006, pp. $475-482$

[30] S. K. Barik, P. K. Mahapatra, R. N. P. Ghoudhary, "Structural and Electrical Properties of $\mathrm{Na}_{1 / 2} \mathrm{La}_{1 / 2} \mathrm{TiO}_{3}$ Ceramics," Applied Physics A: Materials Science \& Processing, Vol. 85, 2006, pp. 199-203. 